\title{
EFFECT OF HABITAT AND FORAGING HEIGHT ON BAT ACTIVITY IN THE COASTAL PLAIN OF SOUTH CAROLINA
}

\author{
JENNIFER M. MENZEL, ${ }^{1}$ U.S. Forest Service, Northeastern Research Station, Parsons, WV 26287, USA \\ MICHAEL A. MENZEL, JR, Alston \& Bird, LLP, Atlanta, GA 30309, USA \\ JOHN C. KILGO, U.S. Forest Service, Southern Research Station, New Ellenton, SC 29809, USA \\ W. MARK FORD, U.S. Forest Service, Northeastern Research Station, Parsons, WV 26287, USA \\ JOHN W. EDWARDS, Division of Forestry, West Virginia University, Morgantown, WV 26505, USA \\ GARY F. MCCRACKEN, Department of Ecology and Evolutionary Biology, University of Tennessee, Knoxville, TN 37996 , USA
}

\begin{abstract}
We compared bat activity levels in the Coastal Plain of South Carolina among 5 habitat types: forested riparian areas, clearcuts, young pine plantations, mature pine plantations, and pine savannas. We used time-expansion radio-microphones and integrated detectors to simultaneously monitor bat activity at 3 heights $(30,10,2 \mathrm{~m})$ in each habitat type. Variation in vegetative clutter among sampling heights and among habitat types allowed us to examine the differential effect of forest vegetation on the spatial activity patterns of clutter-adapted and openadapted bat species. Moreover, monitoring activity at 30,10, and $2 \mathrm{~m}$ permitted us to also compare bat activity above and below the forest canopy. We detected calls of 5 species or species groups: eastern red/Seminole bats (Lasiurus borealis/L. seminolus), eastern pipistrelles (Pipistrellus subflavus), evening bats (Nycticeius humeralis), big brown bats (Eptesicus fuscus), and hoary bats (Lasiurus cinerius). At 2 and $10 \mathrm{~m}$, bat activity was concentrated in riparian areas, whereas we detected relatively low levels of bat activity in upland habitats at those heights. Activity was more evenly distributed across the landscape at $30 \mathrm{~m}$. Bat activity levels above the forest canopy were almost 3 times greater than within or below the canopy. We detected significantly greater activity levels of 2 open-adapted species (hoary and big brown bats) above rather than within or below the forest canopy. However, activity levels of 2 clutter-adapted species (eastern red/Seminole bats and eastern pipistrelles) did not differ above, within, or below the forest canopy. Despite classification as a clutter-adapted species, evening bat activity was greater above rather than within or below the forest canopy. We believe our results highlight the importance of riparian areas as foraging habitat for bats in pine-dominated landscapes in the southeastern United States. Although acoustical surveys conducted below forest canopies can provide useful information about species composition and relative activity levels of bats that forage in cluttered environments, our results showing activity above canopy suggest that such data may not accurately reflect relative activity of bats adapted to forage in more open conditions, and therefore may provide an inaccurate picture of bat community assemblage and foraging habitat use.
\end{abstract}

JOURNAL OF WILDLIFE MANAGEMENT 69(1):235-245; 2005

Key words: bat echolocation, call structure, pine plantations, riparian area, South Carolina, southeast United States, time expansion, wing morphology.

Natural resource managers throughout North America have placed increasing emphasis on understanding the impact of forest management practices on the roosting and foraging behavior of bats (Grindal 1996; Hayes and Adam 1996; Menzel et al. 2000a, 2001a,b, 2002a; Owen et al. 2004). Because of the potential effect timber harvesting can have on both bat roosting and foraging behavior, these data are especially important for those areas heavily impacted by timber harvests such as the Southern Pine Region (SPR) in the southeastern United States where large landscapes of intensively managed forests occur.

Approximately $60 \%$ of the SPR's 79 million ha are forested with the loblolly pine (Pinus taeda)shortleaf pine ( $P$. echinata) cover type and the longleaf pine ( $P$. palustris)-slash pine ( $P$. elliotii)

\footnotetext{
E-mail:jmenzel@fs.fed.us
}

cover type (Barrett 1995). Since the 1960s, the total forest area has declined in the SPR (Barrett 1995, Wear and Greis 2002). In addition to the temporal change in forest area, there has been a dramatic shift in the distribution of pine forests among natural pine stands and pine plantations (U.S. Forest Service 1988), Of the approximately 40 million ha of pine forest in the SPR in 1952, only $2 \%$ consisted of pine plantations, but by 1985 , the percentage of pine plantations had increased to $24 \%$ (U.S. Forest Service 1988). The U.S. Forest Service predicts future shifts in the composition of pine stands in the SPR will be even more dramatic and that the total acreage of southern pine forests will increase to 36.5 million ha by 2030 , of which more than $50 \%$ will be pine plantations (Wear and Greis 2002).

The degree to which bats forage above or below forest canopies and whether or not this varies by vegetation type and structure is a poorly under- 
stood aspect of their ecology. Nonetheless, it is known that some bat species do forage above the canopies of both managed and unmanaged forests throughout North America (Williams et al. 1973, Griffin and Thompson 1982, Fenton and Griffin 1997, Kalcounis et al. 1999, Menzel et al. $2000 \mathrm{~b}$ ). Additionally, analysis of the 3 primary factors (prey abundance, wing morphology, echolocation call structure) that influence foraging habitat selection suggests some bat species are better adapted for foraging in open, clutterless areas such as those above the forest canopy (Simmons and Stein 1980, Neuweiler 1984, Barclay 1985, Aldridge and Rautenbach 1987).

Forest management practices, by impacting insect abundance, insect community composition, and the volume and spatial arrangement of physical clutter in a stand, can have either a positive or negative effect on bat foraging activity. Moreover, the effect of many forest management practices such as pre-commercial thinning, prescribed burning, and commercial clearcut harvest differs greatly at the ground, canopy, and above-canopy levels (Barrett 1995). Unfortunately, most acoustical surveys to date that have examined timber harvest effects on bat foraging have not monitored activity above canopy (Furlonger et al. 1987, Huff et al. 1993, Hickey and Neilson 1995, Grindal 1996, Hayes and Adam 1996, Krusic et al. 1996, Menzel et al. 2002a, Owen et al. 2004). Consequently, there probably is a great underestimation of the use of forest stands by bat species with high wing loadings, high wing-aspect ratios, low call frequencies, and large constant frequency component calls.

Based on previous research, we addressed the general hypotheses that foraging activity of all bat species will be significantly greater in riparian areas than in upland pine forests of a variety of structure-classes and that clutter-adapted species use of canopy layers (heights) will differ from that of open-adapted species (Johnson et al. 2002, Menzel et al. 2003b). On the basis of these hypotheses, we tested the following predictions: (1) foraging activity of open-adapted bats will be greater above than below the forest canopy; (2) foraging activity of clutter-adapted bats will be greater below than above the forest canopy; (3) foraging activity of open-adapted bats will be highest at all 3 heights in clearcuts and above $30 \mathrm{~m}$ in all other habitat types; and (4) foraging activity of clutter-adapted bats will be highest at 2 and $10 \mathrm{~m}$ in riparian areas, at 2 and $10 \mathrm{~m}$ in mature pine forests, and at 2 and $10 \mathrm{~m}$ in pine savannas.

\section{STUDY AREA}

We conducted our study on the U.S. Department of Energy's Savannah River Site (SRS) and MeadWestvaco's Ashley District (AD). The SRS is located in Aiken, Barnwell, and Allendale counties in the Upper Coastal Plain physiographic province of west-central South Carolina, USA, approximately $20 \mathrm{~km}$ northeast of Augusta, Georgia, USA. The AD is centrally located in the Lower Coastal Plain in Charleston and Dorchester counties, approximately $40 \mathrm{~km}$ north of Charleston, South Carolina. Both the SRS and AD have a warm temperate to subtropical climate with average summer and winter air temperatures of 27 and $9{ }^{\circ} \mathrm{C}$, respectively, and an average annual rainfall of $120 \mathrm{~cm}$ (Workman and McLeod 1990).

The SRS is an 80,267-ha National Environmental Research Park, more than $90 \%$ of which is forested. Although forest types include bottomland hardwoods (14.8\%), upland hardwoods $(3.4 \%)$, and pine/hardwood communities (5.2\%), most forested areas on the SRS consist of loblolly, longleaf, and slash pine cover types (61.8\%, Imm and McLeod 2005). Aquatic habitats such as ponds, marshes, and Carolina bays also are common throughout the site (Workman and McLeod 1990). Many of the upland pine forests on the SRS are managed for timber production on long sawtimber rotations ( $>40$ years; Menzel et al. $2003 b$ ).

The $\mathrm{AD}$ is a 33,734-ha forested tract managed by MeadWestvaco Corporation under an Ecosystem-Based Multiple-Use Management Plan. Within this system, approximately $20 \%$ of the land base comprises a corridor network designed to provide connectivity among adjacent forest stands. Most corridors consist of a mix of pine and hardwood species 20-60 years of age. About $50 \%$ of the $\mathrm{AD}$ is devoted to intensively managed pine stands on short rotations for fiber production. Although older longleaf pine stands and both upland and bottomland hardwoods occur on the $\mathrm{AD}$, most stands on the district are loblolly pine managed on a 20-year rotation, and approximately $33 \%$ of the entire area consists of young loblolly pine stands $6-15$ years old.

On the SRS and AD, clearcut stands had been harvested within 2 years of the date of our survey. Only scattered snags $(<3 / \mathrm{ha})$ remained as an overstory component and most understory vegetation was limited to blackberry (Rubus spp.), sweetgum (Liquidamber styracyflua) and newly planted or naturally regenerated loblolly pine. The overstory of the young pine stands (6-15 years old) was dominated by loblolly or longleaf 
pine. The overstory of the mature, closed-canopy pine stands (30-35 years old) consisted primarily of loblolly or longleaf pine. The overstory of the open-canopied pine savannas was dominated by widely spaced longleaf pine. The overstory of the riparian areas was composed of sweetgum, black willow (Salix nigra), red maple (Acer rubrum), blackgum, and green ash (Fraxinus pennsyloanicum). Because our riparian survey locations were centered in open areas on the edge of streams or ponds, few overstory trees actually were located within $10-20 \mathrm{~m}$ of our survey locations.

\section{METHODS}

\section{Study Design}

We used a randomized complete block design to compare bat foraging among 5 vegetation types: clearcuts, young pine stands $6-15$ years in age, closed-canopy pine stands 30-35 years in age, opencanopy longleaf pine savannas, and riparian areas. Two blocks were located on the SRS and 1 block was located on the AD. Each block consisted of 1 replicate of the 5 vegetation types. Because site productivity was higher on the AD than the SRS, and because our study design required that all stands within the same treatment group have similar vegetational structure, we selected stands at the higher and lower end of the age bracket on the SRS and $\mathrm{AD}$ for young pine stands and closed-canopy pine stands, respectively. We randomly selected stands to survey from a pool of sites with similar vegetation structure within each age category.

\section{Capture}

We captured bats using mist nets to determine the bat species that occurred on each of the 3 sample blocks and to obtain morphometric data. We also considered data from previous surveys in the area (Menzel et al. 2003a) in determining species present. We placed mist nets $(2.6 \times 12-\mathrm{m}$; $32.0 \mathrm{~mm}$ mesh, Avinet, Inc., Dryden, New York, USA) over ponds, roads, or streams located in or near $(<1,000 \mathrm{~m})$ surveyed stands. Data collected from captured individuals included species, mass, and forearm length.

\section{Wing Morphology}

Although simple wing measurements (e.g., wing length, wing width, forearm length) can provide insight about the maneuverability of a foraging bat (Findley et al. 1972), more intregrated morphological metrics, such as wing aspect ratio (wing length/wing width) and wing loading (mass/wing area), typically have been better predictors of a species' maneuverability (Aldridge 1987, Kalcounis and Brigham 1995, Birch 1997). Therefore, we collected wing tracings of the outline of each captured bat's left wing from the cranial attachment of the propatagium and continuing to the caudal attachment of the plagiopatagium (Hill and Smith 1984), but excluding the uropatagium. We measured each wing length and width at the 5 th digit and determined its area using a polar planimeter (Wenger 1984). To determine wing aspect ratio, we divided wing length by its width. We determined wing loading by dividing an individual's mass by 2 times the wing area. We were able to separate the 5 most common bat species or species groups at SRS and AD into clutter-adapted or open-adapted foraging guilds based on their wing morphology and echolocation call structure. We placed eastern pipistrelles, evening bats, eastern red bats, and Seminole bats in the clutteradapted foraging ensemble and placed hoary and big brown bats in the open-adapted ensemble.

\section{Acoustical Monitoring}

Between 15 May and 10 August 2000, we used time-expansion integrated detectors and radiomicrophones to survey levels of bat activity simultaneously at 3 sampling heights $(30,10$, and $2 \mathrm{~m})$ in each of the 5 habitat types. The time-expansion circuitry employed in the integrated units consisted of the circuit board used in Pettersson D-240 detectors (Pettersson Elektronik, Tallbacksvagen, Sweden), modified so that it regulated the power flow between a 3-volt gel cell battery and a Sony WM-D3 professional stereo cassette-recorder (Sony Corporation, Tokyo, Japan). The timeexpansion circuitry employed in the radio-microphones also consisted of the circuit boards used in Pettersson D-240 detectors. [For a detailed description of the construction of the time expansion integrated units and radio-microphones, see Menzel (2003b).] The sampling cones of all the detectors were adjusted on the ground prior to deployment to ensure that the volume of sampling space was equal among all habitat types.

The relative position of the three sampling heights in relation to the forest canopy differed among the 5 habitat types. In clearcuts, there was no vegetative clutter in the detector sampling cones at any of the 3 sampling heights and the detectors at $30 \mathrm{~m}$ were approximately $2-5 \mathrm{~m}$ above the forest canopy of the surrounding stand. Because of the density of pines in young planta- 
tions, there was more clutter in the sampling cones of both the 2 - and $10-\mathrm{m}$ detectors. The $10-\mathrm{m}$ detectors were approximately $3 \mathrm{~m}$ below the forest canopy and the 30 -m detectors were approximately $17 \mathrm{~m}$ above it. In closed-canopy, mature pine stands there was a moderate amount of clutter in the sampling cone of the $2-m$ detectors, which were just above forest ground cover, and 10$\mathrm{m}$ detectors, which were just below the forest canopy. Because of the dominant role of frequent prescribed burning in maintaining the opencanopy pine savannas (Edwards et al. 2000, Menzel et al. $2003 b$ ), there was virtually no understory or midstory vegetation and, as a result, little clutter in the sampling cones of the 2- or 10-m detectors in these stands. In the riparian areas, we oriented the detectors to monitor activity over open water where there was little vegetation in the sampling cones of the 2 - or $10-\mathrm{m}$ detectors in the riparian stands. In the closed-canopy mature pine stands, the open-canopy pine savannas, and riparian stands, the 30-m detectors were located $2-5 \mathrm{~m}$ above the forest canopy with the sampling cone pointing parallel to the top of the canopy.

We conducted surveys nightly except during periods of rain or winds $>9 \mathrm{~km} / \mathrm{h}$. We sampled 2-3 habitats each night and deployed detectors at dusk, monitoring them continuously through the night. Sampling was conducted simultaneously at all sampling heights. We suspended 1 integrated detector at 2 and $10 \mathrm{~m}$ at each site via a rope and pulley system attached to $10-\mathrm{m}$ antenna poles. To monitor activity at $30 \mathrm{~m}$, we suspended the radiomicrophones $5 \mathrm{~m}$ below $14-\mathrm{m}^{3}$ helium-filled blimps. The shells of each blimp were hand-constructed from rip-stop nylon and the bladders consisted of $600 \mathrm{~g}$, weather balloons (Scientific Sales, Lawrenceville, New Jersey). We anchored blimps using $50-\mathrm{kg}$ test Dacron fishing line attached to industrial air compressor hose reels (Rapid Reel ${ }^{\circledR}$, Reel Quick, Inc., Lincoln, Nebraska, USA). We controlled blimp height by reeling out $30 \mathrm{~m}$ of tether line. We attached a digital wristwatch, whose hourly chimes contained an ultrasonic component (Krusic et al. 1996), near the microphone of each integrated unit and radiomicrophone to monitor the functioning of each detector throughout the night.

\section{Echolocation Call Analysis}

In conjunction with mist-netting to establish bat species assemblages on the study areas, we affixed chemoluminescent light tags between the scapula of 7-10 individuals of each species cap- tured on the SRS and $\mathrm{AD}$ and recorded their search phase echolocation calls. We used these "known identification" calls, along with call libraries established earlier on the SRS (Menzel et al, 2002a), to identify unknown calls collected during this study. We downloaded all calls from audiotape to laptop computers using Bat Sound software (Pettersson Elektronik, Tallbacksvagen, Sweden; Version 1.2). We recorded the number of call sequences (commonly termed bat passes, Thomas 1988; hereafter we use the terms "calls" and "call sequence" interchangeably) and feeding buzzes (Griffin et al. 1960) detected each night at 30,10 , and $2 \mathrm{~m}$ in each habitat type. We used qualitative analysis to identify the bat species that emitted call sequences containing $>3$ calls by comparing the spectrograms and oscillograms of our known identification calls to those of unknown calls (Fenton and Bell 1981, O'Farrell et al. 1999). We categorized calls with characteristics dissimilar to the calls in our call library, and all call sequences containing $<3$ calls, as unidentifiable.

\section{Statistical Analysis}

A Wilks' test indicated the wing aspect ratio and wing loading data were normally distributed (SAS Institute 1990). Therefore, we used 1-way analysis of variance (ANOVA) to compare the wing aspect ratio and wing loading of the 5 species or species groups we detected during our study (SAS Institute 1990). We used Duncan's multiple means comparison to determine which means differed (SAS Institute 1990). Significance was determined at $P \leq 0.05$.

We used 1-way ANOVA with a randomized complete block design to compare levels of bat activity among the 5 habitat types at 30,10 , and $2 \mathrm{~m}$, with location serving as the block. Although we sampled for 3 nights at each height in each stand, using an error term that considered each night sample an independent replicate would have been temporal pseudoreplication (Hurlbert 1984). Therefore, we substituted appropriate error terms into the ANOVA so that temporal replicates served as subsamples (Dowdy and Wearden 1991).

For each significant ANOVA test, we used orthogonal linear contrasts to determine how levels of bat activity differed among the habitat types. We were able to make a priori predictions about how foraging activity levels would differ among stands based on the vegetation density in each habitat type (Montgomery 1991). We used 5 treatment levels, enabling us to conduct 4 appropriate and biologically meaningful contrasts: 
Table 1. Comparison of wing aspect ratio and wing loading among 5 bat species/groups detected foraging in the Coastal Plain of South Carolina, USA, summer 2000 ( $\mathrm{LACl}=$ Lasiurus cinerius, EPFU $=$ Eptesicus fuscus, $\mathrm{LABO} / \mathrm{SE}=\mathrm{L}$. borealis/seminolus, NYHU $=$ Nyctice 1 s humeralis, PISU = Pipistrelius subflavus). Means followed by the same letter are not significantly different (Duncan's Multiple Means Comparison; SAS Institute 1990).

\begin{tabular}{|c|c|c|c|c|c|c|c|c|c|c|c|c|}
\hline & \multicolumn{4}{|c|}{ Open area foragers } & \multicolumn{6}{|c|}{ Clutter adapted foragers } & \multirow[b]{3}{*}{$F$} & \multirow[b]{3}{*}{$P$} \\
\hline & \multicolumn{2}{|c|}{$\mathrm{LACl}(n=7)$} & \multicolumn{2}{|c|}{$\operatorname{EPFU}(n=15)$} & \multicolumn{2}{|c|}{$\mathrm{LABO} / \mathrm{SE}(n=25)$} & \multicolumn{2}{|c|}{ NYHU $(n=5)$} & \multicolumn{2}{|c|}{$\operatorname{PISU}(n=20)$} & & \\
\hline & Mean & $\overline{S E}$ & Mean & SE & Mean & $\mathrm{SE}$ & Mean & $\mathrm{SE}$ & Mean & SE & & \\
\hline Wing aspect ratio & $2.46 \mathrm{~A}$ & 0.053 & $2.23 \mathrm{~B}$ & 0.042 & $2.29 \mathrm{BC}$ & 0.031 & $2.10 \mathrm{C}$ & 0.039 & $2.15 \mathrm{C}$ & 0.036 & 7.29 & 0.001 \\
\hline Wing loading ${ }^{a}$ & $0.17 \mathrm{~A}$ & 0.009 & $0.17 \mathrm{~A}$ & 0.006 & $0.13 \mathrm{~B}$ & 0.006 & $0.15 \mathrm{~B}$ & 0.006 & $0.10 \mathrm{C}$ & 0.004 & 26.97 & 0.001 \\
\hline
\end{tabular}

$\mathrm{g} / \mathrm{cm}^{2}$.

riparian vs. upland, cluttered upland forest vs. open upland habitats, early succession forests vs. late succession forests, and cluttered riparian vs. open riparian. We classifed cluttered forests as 2 $\mathrm{m}$ in young pine, $2 \mathrm{~m}$ in mature pine, 2 and $10 \mathrm{~m}$ in pine savannas, and $10 \mathrm{~m}$ in mature pine stands. We classified open upland habitats as 30,10 and $2 \mathrm{~m}$ in clearcuts, $30 \mathrm{~m}$ in pine savannas, 10 and 30 $\mathrm{m}$ in young pine stands, and $30 \mathrm{~m}$ in mature pine stands. Open riparian areas were those sampled at $30 \mathrm{~m}$, while cluttered riparian areas were those sampled at 2 and $10 \mathrm{~m}$.

We performed a Wilcoxon test on ranked data to compare levels of bat activity above and below forest canopies (SAS Institute 1990). Because clearcuts and riparian areas lacked canopies as we defined them, we used data collected only in young pine plantations, mature pine stands, and pine savannas for comparing bat activity above $(30 \mathrm{~m})$ and below $(2$ and $10 \mathrm{~m})$ the forest canopy.

\section{RESULTS}

We surveyed bat activity for 47 nights (124 detector nights) between May and August 2000. We attempted to collect recordings for 3 nights (i.e., 3 subsamples) at each height in each stand (135 detector nights). However, because of inclement weather and equipment malfunction, we were able to collect only 2 subsamples from some heights in a few stands. Overall, we recorded 1,595 bat echolocation calls.

We collected wing morphology data from hoary bats $(n=7)$, big brown bats $(n=15)$, members of the eastern red/Seminole bat group $(n=25)$, evening bats $(n=5)$, and eastern pipistrelles $(n=$ 20). Wing aspect ratio and wing loading differed among the 5 species or species groups (Table 1). We classified species as adapted for foraging in cluttered habitat or for foraging in open, uncluttered habitat (Menzel 2003b).

Based on a comparison between the calls in our call library and the unknown calls we recorded, along with the similarity in the qualitative char- acteristics of the time-expansion calls in our call library to the frequency division calls in a more expansive library (previously established on the study areas with Anabat detectors; Menzel 1998, Menzel et al. 2002a), we placed $>98 \%$ of the timeexpansion calls recorded into 5 species or species groups. These included members of the eastern $\mathrm{red} /$ Seminole group ( 826 calls; species with similar call characteristics commonly are classified into species groups, Fenton 1983, Kalcounis et al. 1999, Menzel et al. 2000b), eastern pipistrelles (70 calls), evening bats (393 calls), big brown bats ( 235 calls), and hoary bats (53 calls). Each of these species had been previously collected on or near both study areas (Menzel et al. 2003a) and, with the exception of the big brown bat, we captured each species on the study areas during this study. Despite the additional information contained in time-expansion calls, such as the presence of harmonics and call intensities more detailed than those obtained from the frequency division methods, we still were not able to distinguish between the calls of eastern red and Seminole bats.

Total flight activity and activity of all 5 species/groups was substantially greater in riparian areas than in upland sites (Table 2). Total bat activity was greater in open upland habitats than in cluttered upland forests. Red/Seminole bat and eastern pipistrelle activity was not significantly different in either habitat type (Table 2). No bat species had a greater presence in either early or late succession forests (Table 2). Total bat activity at 2 and $10 \mathrm{~m}$ in riparian areas was significantly higher for all 5 species than at $30 \mathrm{~m}$ above riparian areas (Table 2).

Total bat activity for all species combined did not differ among the 3 survey heights. We recorded 511 calls $(32.0 \%)$ at $2 \mathrm{~m}, 678$ calls $(42.5 \%)$ at $10 \mathrm{~m}$, and 406 calls $(25.5 \%)$ at $30 \mathrm{~m}$. Although overall bat activity decreased rather substantially as survey height increased above the canopy in riparian areas $(34.7 \%$ at $2 \mathrm{~m}, 51.3 \%$ at $10 \mathrm{~m}$, 
Table 2. Comparison of bat activity (calls/night) between riparian and upland sites, cluttered upland forests and open habitats, early-succession and late-succession forests, and cluttered riparian and open riparian areas in the Coastal Plain of South Carolina, USA, May-Aug 2000 (means and SE are from untransformed data, Fand $P$ are results of orthogonal contrasts performed on ranked data).

\begin{tabular}{|c|c|c|c|c|c|c|}
\hline Species & Mean & $\mathrm{SE}$ & Mean & SE & $F$ & $P$ \\
\hline & \multicolumn{2}{|c|}{ Riparian areas } & \multicolumn{2}{|c|}{ Upland sites } & & \\
\hline Red and Seminole bats & 29.06 & 10.180 & 1.27 & 0.919 & 75.52 & 0.001 \\
\hline Eastern pipistrelles & 2.02 & 0.813 & 0.18 & 0.179 & 70.72 & 0.001 \\
\hline Evening bats & 12.24 & 5.382 & 0.94 & 0.474 & 49.19 & 0.001 \\
\hline Big brown bats & 4.13 & 1.637 & 1.26 & 0.926 & 56.13 & 0.001 \\
\hline Hoary bats & 0.38 & 0.303 & 0.36 & 0.205 & 10.37 & 0.003 \\
\hline \multirow[t]{2}{*}{ Total bat activity } & 48.18 & 12.071 & 4.15 & 2.341 & 65.59 & 0.001 \\
\hline & \multicolumn{2}{|c|}{ Cluttered forests } & \multicolumn{2}{|c|}{ Open habitats } & & \\
\hline Red and Seminole bats & 1.42 & 1.091 & 1.16 & 0.796 & 0.00 & 0.976 \\
\hline Eastern pipistrelles & 0.33 & 0.315 & 0.08 & 0.081 & 0.16 & 0.693 \\
\hline Evening bats & 0.69 & 0.463 & 1.12 & 0.481 & 17.42 & 0.001 \\
\hline Big brown bats & 0.11 & 0.086 & 2.04 & 1.525 & 6.69 & 0.013 \\
\hline Hoary bats & 0.06 & 0.037 & 0.58 & 0.325 & 8.31 & 0.006 \\
\hline \multirow[t]{2}{*}{ Total bat activity } & 2.72 & 1.959 & 5.17 & 2.613 & 10.63 & 0.002 \\
\hline & \multicolumn{2}{|c|}{ Early succession } & \multicolumn{2}{|c|}{ Late succession } & & \\
\hline Red and Seminole bats & 0.90 & 0.528 & 1.64 & 1.310 & 0.05 & 0.821 \\
\hline Eastern pipistrelles & 0.07 & 0.071 & 0.30 & 0.287 & 0.32 & 0.573 \\
\hline Evening bats & 0.90 & 0.370 & 0.98 & 0.578 & 0.49 & 0.489 \\
\hline Big brown bats & 2.04 & 1.624 & 0.42 & 0.227 & 1.23 & 0.215 \\
\hline Hoary bats & 0.51 & 0.290 & 0.21 & 0.120 & 1.17 & 0.285 \\
\hline \multirow[t]{2}{*}{ Total bat activity } & 4.58 & 2.433 & 3.72 & 2.247 & 0.03 & 0.860 \\
\hline & \multicolumn{2}{|c|}{ Cluttered riparian } & \multicolumn{2}{|c|}{ Open riparian } & & \\
\hline Red and Seminole bats & 36.79 & 10.317 & 13.5 & $\overline{9.906}$ & 15.22 & 0.001 \\
\hline Eastern pipistrelles & 2.60 & 0.943 & 0.86 & 0.553 & 12.74 & 0.001 \\
\hline Evening bats & 15.58 & 6.015 & 5.57 & 4.117 & 13.60 & 0.001 \\
\hline Big brown bats & 4.91 & 1.901 & 2.57 & 1.110 & 7.57 & 0.009 \\
\hline Hoary bats & 0.82 & 0.363 & 0.29 & 0.184 & 4.25 & 0.046 \\
\hline Total bat activity & 60.84 & 12.376 & 22.86 & 11.461 & 11.24 & 0.002 \\
\hline
\end{tabular}

$14.0 \%$ at $30 \mathrm{~m}$ ); the opposite trend was observed above upland stands $(25.4 \%$ at $2 \mathrm{~m}, 20.3 \%$ at 10 $\mathrm{m}, 54.3 \%$ at $30 \mathrm{~m}$ ). No bat species or species group was more active below than above the forest canopy (Table 3). In contrast, evening bats, big brown bats, and hoary bats were more active above than below the forest canopy (Table 3). On average, when riparian habitats were omitted, total bat activity above the forest canopy was 3.6

Table 3. Comparison of bat activity (calls/night) above the forest canopy with levels of activity below the canopy of pine forests in the Coastal Plain of South Carolina, USA, May-Aug 2000 (means and SE are from untransformed data, $T$ and $P$ are results of tetests performed on ranked data).

\begin{tabular}{lcccccccc}
\hline & \multicolumn{2}{c}{ Above canopy } & & \multicolumn{3}{c}{ Below canopy } & & \\
\cline { 2 - 3 } \multicolumn{1}{c}{ Species } & Mean & SE & & Mean & SE & & $T$ & $P$ \\
\hline Red and Seminole bats & 1.16 & 1.396 & & 0.71 & 0.762 & 1.24 & 0.159 \\
Eastern pipistrelles & 0.05 & 0.340 & & 0.05 & 0.302 & 0.39 & 0.552 \\
Evening bats & 1.11 & 0.660 & & 0.36 & 0.331 & 5.71 & 0.048 \\
Big brown bats & 0.84 & 0.113 & & 0.32 & 0.064 & 29.12 & 0.001 \\
Hoary bats & 0.47 & 0.038 & & 0.22 & 0.026 & 31.62 & 0.001 \\
Total bat activity & 3.84 & 2.660 & & 1.04 & 1.181 & 3.75 & 0.094 \\
\hline
\end{tabular}

times greater than below the canopy (Table 3 ).

\section{DISCUSSION}

Based on comparisons of spatial patterns of bat activity that we postulated and detected, we were able to accurately predict the general foraging patterns of four of the 5 bat species or species groups that commonly occur on the SRS and the $A D$ in the Atlantic Coastal Plain region of South Carolina. Flight activity of all bat species was indeed greater in riparian areas than upland forests. With regard to our second hypothesis, we incorrectly predicted that flight activity of clutteradapted species would be greater below than above the forest canopy. This may have been partially due to the fact that we classified evening bats as clutter-adapted species. We detected almost 3 times as much evening bat activity above rather than below the forest canopy. A review of the general spatial distribution of evening bat activity across the landscape reveals that evening bats rarely were detected in the moderately cluttered areas below the canopy in mature pine forests. The activity of the other clutter-adapted species was dispersed more evenly above and below the forest canopy. We detected significantly greater levels of big brown and hoary bat activity above rather than below the forest canopy, thus supporting our third hypothesis. Activity patterns we detected supported our fourth hypothesis that flight activity of the clutter-adapted species would be greatest at 2 and $10 \mathrm{~m}$ above riparian areas, 

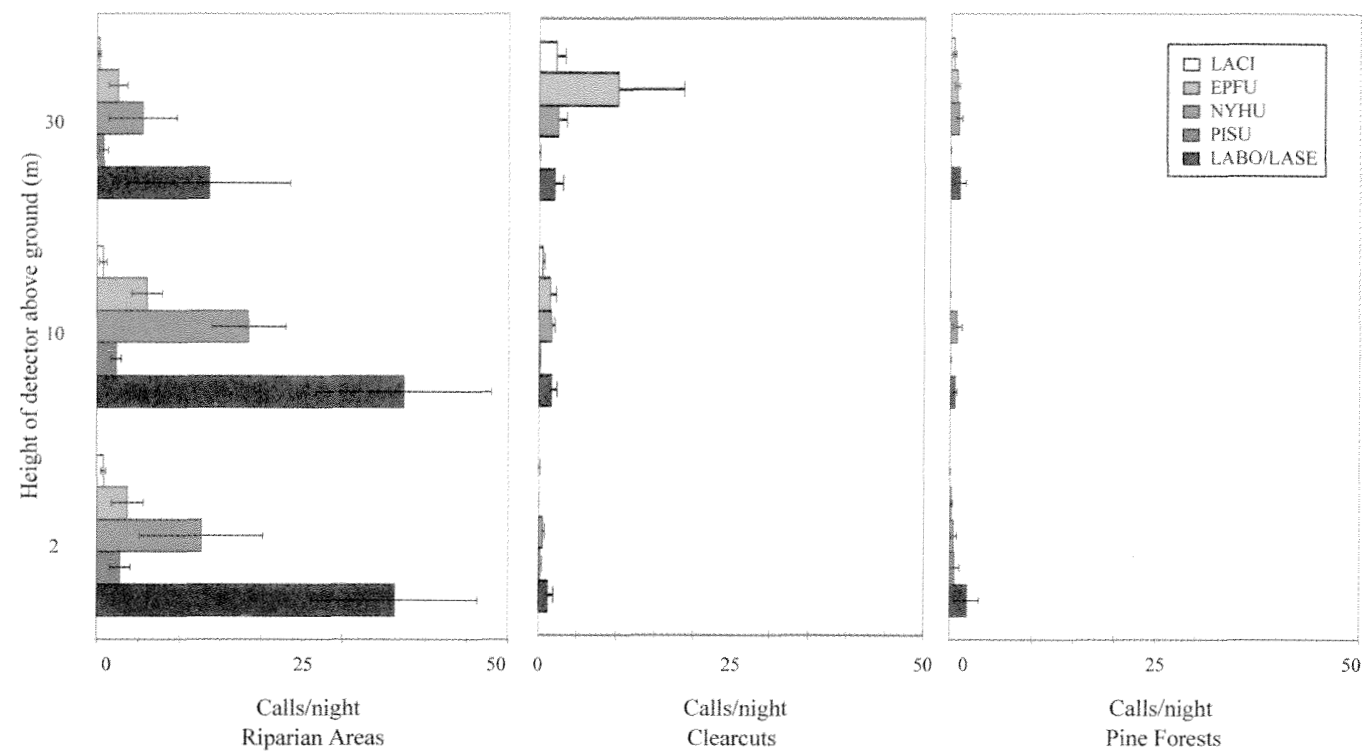

Fig. 1. Comparison of activity (Mean and SE) of eastern red/Seminole bats (LABOSE), eastern pipistrelles (PISU), evening bats (NYHU), big brown bats (EPFU), and hoary bats (LACI) among riparian areas, clearcuts, and pine forests at 2, 10, and $30 \mathrm{~m}$ above the forest floor during May-August 2000 in the Coastal Plain of South Carolina, USA.

below and above the canopy at 2 and $30 \mathrm{~m}$ in mature pine forests, and at 2 and $10 \mathrm{~m}$ in pine savannas (Figs. 1,2). The level of clutter at 2 and $10 \mathrm{~m}$ in young pine forests and at $10 \mathrm{~m}$ in mature pine forests was possibly too great to allow even clutter-adapted species to forage efficiently. Additionally, species adapted to gleaning, such as Rafinesque's big-eared bat, probably do occur in these cluttered habitats, but are virtually undetectable using acoustical monitors (Menzel et al.

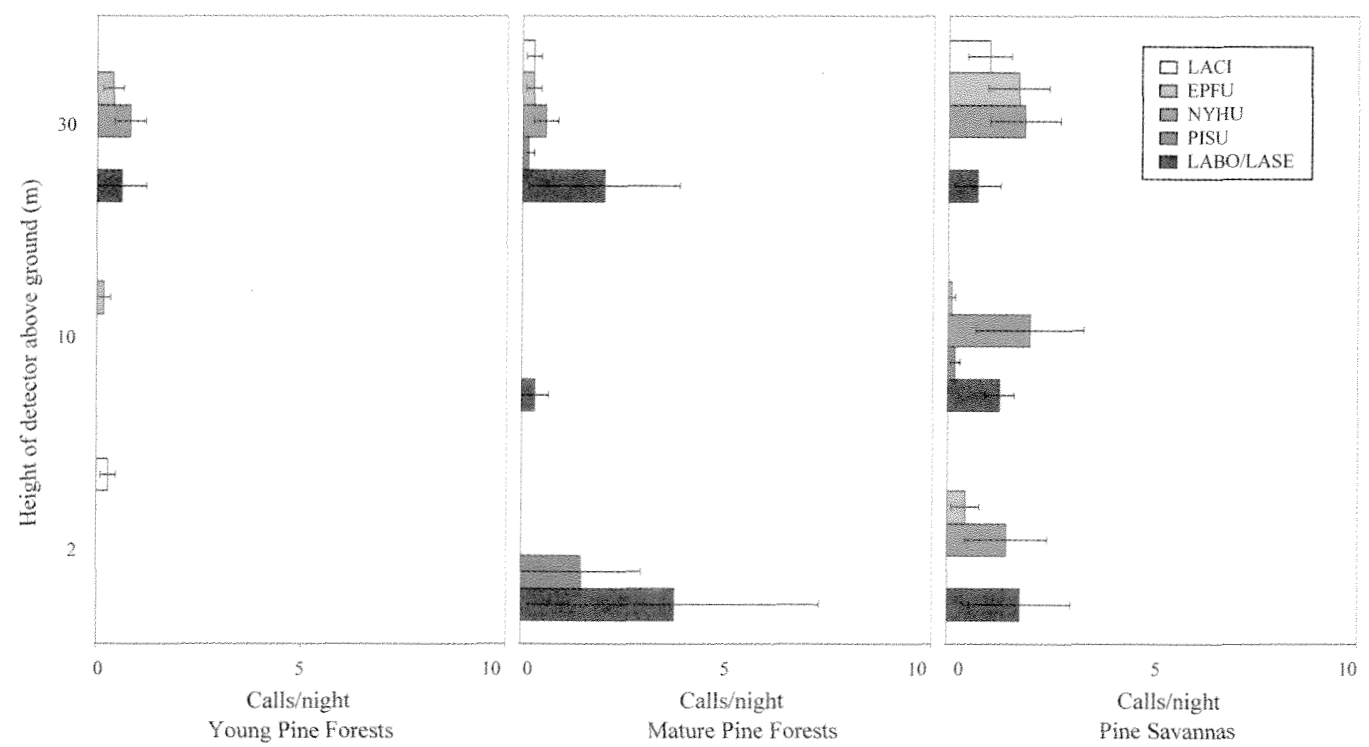

Fig. 2. Comparison of activity (Mean and SE) of eastern red/Seminole bats (LABOSE), eastern pipistrelles (PISU), evening bats (NYHU), big brown bats (EPFU), and hoary bats (LACl) among young pine plantations, mature pine forests, and pine savannas at 2,10 , and $30 \mathrm{~m}$ above the forest floor during May-August 2000 in the Coastal Plain of South Carolina, USA. 
2001a). The level of clutter at all 3 heights in clearcuts and at $30 \mathrm{~m}$ above young pine forests was too low for efficient foraging by clutter-adapted bats. Clutter-adapted species were able to forage efficiently around the boles of trees at $2 \mathrm{~m}$ in the mature pine forests and pine savannas and, because of the open, park-like nature of the pine savannas, around the crowns of individual pines in pine savannas. Additionally, because the $30 \mathrm{~m}$ detectors were located just above the forest canopy in the mature pine forests and pine savannas, these detectors detected relatively high levels of bats foraging along the horizontal edge formed by the top of the forest canopy.

Still, levels of bat activity that we observed were on the lower end of the total range reported for most other forested regions of eastern North America (Hart et al. 1993). Bat activity levels vary from a low of 15 calls/night in regenerating softwood clearcuts in New England (Krusic et al. 1996) to highs of $>2 \mathrm{call} / \mathrm{min}$ over wooded streams in northwest Georgia (Johnson et al. 2002). We also detected less activity than previous surveys conducted in other forest community types at SRS including small forest gaps in bottomland hardwoods ( 7 calls $/ 15 \mathrm{~min}$ ), Carolina bays $(6$ calls $/ 15 \mathrm{~min})$, and upland pine/mixed hardwood forests $(2$ calls $/ 15 \mathrm{~min}$, Menzel et al. 2002a). Additionally, we discovered activity levels below those recorded in western North America (Kalcounis et al. 1999) where levels ranged from 0 calls/night in young, unthinned forests (Erickson and West 1996) to $>100$ calls/night in aspen (Populus tremuloides)-white spruce (Picea glauca) forests (Kalcounis et al. 1999).

Although the activity levels of bats we detected were low compared to those in other forest communities, variations in activity among vegetation types were similar to previous reports. For example, the relation between bat activity and riparian areas is apparent in the literature. Our results also indicate that bats are most active in the early and late seral stages of upland pine forests in the Coastal Plain and are least active in intermediate stages, consistent with reports from Erickson and West (1996, 2003) and Parker et al. (1996). Thomas (1988) also found higher bat activity in late seral stages and attributed this activity to a higher abundance and diversity of roosts in these older stands. Similarly, Humes et al. (1999) detected higher amounts of bat activity in old-growth and thinned stands than unthinned stands in western Oregon.

Little empirical data exists on foraging activity above the forest canopy. Comparison of our results to those of the only previous southeastern United States study to monitor activity above the surrounding canopy suggests the above-canopy levels of activity we recorded also were low (Menzel et al. 2000b). In the Georgia Piedmont, Menzel et al. $(2000 b)$ recorded an average of 9 and 11 calls/hour at heights of 1 and $21 \mathrm{~m}$ above the forest canopy, respectively, whereas the highest level of activity we detected at $30 \mathrm{~m}$ was 23 calls/night over riparian areas. Kalcounis et al. (1999) monitored activity within and above the canopy of 3 forest types in British Columbia and found that use of forest type differed among bat species or species groups. The relatively low levels of activity we detected in upland pine stands (compared to riparian areas) may have been a result of a scarcity of insect prey in these stands. Because we did not monitor insect densities, it is not possible to define, quantitatively, the relation between bat activity levels and the abundance of insect prey in each community type. Insect densities typically are higher in cluttered rather than open habitats (Kalcounis and Brigham 1995, Grindal 1996, Hanula et al. 2000), thus insect densities should have been relatively high under and within forest canopies we surveyed, and relatively low in clearcuts and over forest canopies. If insect densities followed predictions based on forest clutter, our results paradoxically suggest foraging activity was lowest in the areas with the greatest insect densities.

An alternative explanation is that insect densities did not follow predictions based on abundance of forest clutter. Despite predictions suggesting that insect densities should be greater in cluttered forested stands than in open areas such as clearcuts, previous studies also have found relatively low levels of bat activity in pine forests (Grindal 1996, Kalcounis et al. 1999, Tibbels and Kurta 2003). Kalcounis et al. (1999) suggested that bat activity may be lower in coniferous stands because resins synthesized by conifers as a defense against herbivory may result in lower insect densities (Funk and Crouteau 1994). If insect densities in pine stands are suppressed as a result of the antiherbivory compounds pines produce, the bat activity patterns we observed may have been correlated with concentrations of their insect prey (Asaro et al. 2003).

Comparison of bat activity for each species or species group at each height among habitat types indicates that, with 1 exception, bat foraging patterns fit our predictions based on classification of bats into the open- or clutter-adapted ensembles. Contrary to predicted foraging patterns, evening 
bat activity was almost 3 times greater above than below the forest canopy (Table 3). Evening bats were not detected below or within the canopy of young or mature pine forests. However, evening bats commonly were detected flying in the less cluttered areas below and around the crowns of individual trees in pine savannas. Additionally, during previous studies we commonly observed radio-tagged evening bats foraging around the crowns of individual pines and along the horizontal edge created at the top of the forest canopy (M. A. Menzel, unpublished data). Our results suggest that evening bats are adapted for foraging in habitats with intermediate amounts of clutter. The relatively high levels of above canopy flight activity we detected may result from the exploitation by evening bats of expansive "horizontal edge" habitat that exists along the top of forest canopies (Kalcounis et al. 1999).

\section{MANAGEMENT IMPLICATIONS}

In upland stands, we detected almost 4 times as many calls above the forest canopy as we detected within or below the canopy. Additionally, the relative difference in activity levels above and below the forest canopy differed among bat species. Accordingly, acoustic monitoring protocols that monitor activity only below or within a forest canopy may underrepresent stand use by bats adapted to forage in more open, uncluttered environments. That we detected higher levels of bat activity in pine savannas and lower levels in young pine plantations and within the canopy of mature pine stands illustrates that none of the species we studied only foraged in highly cluttered environments. The overall activity patterns we observed suggest no single forest structure provides optimal foraging habitat for all 5 bat species that occur on SRS or AD. Although heavily cluttered habitats such as young pine plantations were not used by any of the species we detected, maintaining a mix of moderately cluttered and uncluttered habitats across a wide landscape could potentially provide foraging habitat for a variety of bat species in the southeastern United States.

Forest management on upland sites has been shown to increase bat activity levels through the creation of patches of relatively uncluttered habitat in which bats may forage more easily (Grindal and Brigham 1998). It should be remembered, however, that in addition to providing foraging habitat, upland sites provide important roosting habitat for many bat species (Menzel 1998, Menzel et al. 2000a, Lacki and Schwierjohann 2001,
Mager and Nelson 2001, Fellers and Pierson 2002, Britzke et al. 2003); thus, forest managers should also attempt to retain potential roost trees on upland sites. Forest management that creates structural and biological complexity and heterogeneity should be beneficial for bats. Additionally, forest practices used to manage red-cockaded woodpeckers (Picoides borealis), such as longer rotations, prescribed fire and periodic thinnings, could also benefit bats by creating open foraging habitat within dense upland stands (Conner et al. 1996, Menzel et al. 2001c).

\section{ACKNOWLEDGMENTS}

We thank A. J. Baker, J. C. Corcoran, D. E. Linden, and L. S. B. Sparks for field assistance and M. Baughman for providing access to study sites on Mead-Westvaco's Ashley District. L. Butler, J. T. Anderson, and J. T. Petty provided editorial comment. Funding and support for this study was provided by the U.S. Department of Energy-Savannah River Operations Office through the U.S. Forest Service-Savannah River and the U.S. Forest Service Southern Research Station under Interagency Agreement DE-AI09-76SR00056 and the National Council of the Paper Industry for Air and Stream Improvement. Additional support was provided by West Virginia University's Arlen G. and Louise Stone Swiger Fellowship, Division of Forestry, West Virginia University, and MeadWestvaco Corporation's Forest Resources Division.

\section{LITERATURE CITED}

ALDRIDGE, H. D. J. N. 1987. Turning flight of bats. Journal of Experimental Biology 128:419-425.

- , AND I. L. Ravtenbach. 1987. Morphology, echolocation, and resource partitioning in insectivorous bats. Journal of Animal Ecology 56:763-778.

Asaro, C., C. J. Fettig, K. W. McCravy, J. T. Nowak, and C. W. Berisford. 2003. The Nantucket pine moth (Lepidoptera: Tortricidae): a literature review with management implications. Journal of Entomological Science 38:1-40.

BARCLAY, R. M. R. 1985. Long-verses short-range foraging strategies of hoary (Lasiurus cinereus) and silverhaired (Lasionycteris noctivagans) bats and the consequences for prey selection. Canadian Journal of Zoology 63:2507-2515.

BARRETT, J. W. 1995. Regional silviculture of the United States. John Wiley and Sons, New York, USA.

BirCH, J. M. 1997. Comparing wing shape of bats: the merits of principal-components analysis and relativewarp analysis. Journal of Mammalogy 78:1187-1198.

Brttzke, E. R., M. J. Harvex, AND S. C. LOEB. 2003. Indiana bat, Myotis sodalist, maternity roosts in the southeastern United States. Southeastern Naturalist 2:235-242.

Conner, R. N., D. C. Rudolph, D. SAenz, AND R. R. SCHAEFER. 1996. Red-cockaded woodpecker nesting success, forest structure, and southern flying squirrels 
in Texas. Wilson Bulletin 108:697-711.

DOWDY, S., AND S. WEARDEN. 1991. Statistics for research. Second edition. John Wiley and Sons, New York, USA EDWARDS, J. W., W. M. SMATHERS, E. T. LEMASTER, AND W. L. JARvis. 2000. Savannah River red-cockaded woodpecker management plan. Final project report to U.S. Forest Service Savannah River, New Ellenton, South Carolina, USA.

ERICKSON, J. L., AND S. D. West. 1996. Managed forests in the Western Cascades: the effect of seral stage on bat habitat use patterns. Pages 215-227 in R. M. R. Barclay and R. M. Brigham, editors. Bats and Forests Symposium, Victoria, British Columbia, 19-21 October 1995. Working Paper 23/1996. Canadian Research Branch, British Columbia Ministry of Forests, Victoria, Canada.

-2003. Associations of bats with local structure and landscape features of forested stands in western Oregon and Washington. Biological Conservation 109:95-102.

Fellers, G. M., And E. D. Pierson. 2002. Habitat use and foraging bevaior of Townsend's big-eared bat (Corynorhinus townsendii) in coastal California. Journal of Mammalogy 83:167-177.

Fenton, M. B. 1983. Just bats. University of Toronto Press, Toronto, Ontario, Canada.

- AND G. P. BELL. 1981. Recognition of species of insectivorous bats by their echolocation calls. Journal of Mammalogy 62: 233-243.

—, AND D. R. GRIFFIN. 1997. High-altitude pursuit of insects by echolocating bats. Journal of Mammalogy $78: 247-250$.

Findley, J. S., E. H. Studier, and D. E. Whlson. 1972. Morphologic properties of bat wings. Journal of Mammalogy 53:429-444.

FUnK, C., AND R. CROTEAU. 1994. Diterpenoid resin acid biosynthesis in conifers: characterization of 2 cytochrome P450-dependent monooxygenases and an aldehyde dehydrogenase involved in adietic acid biosynthesis. Archive of Biochemistry and Biophysics $308: 258-266$

Furlonger, C. L., H. J. Dewar, and M. B. Fenton. 1987. Habitat use by foraging insectivorous bats. Canadian Journal of Zoology 65: 284-88.

Griffin, D. R., F. A. Webster, And C. R. Michael. 1960. The echolocation of flying insects by bats. Journal of Animal Behavior 8:141-154.

- AND D. Thompson. 1982. High altitude echolocation of insects by bats. Behavioral Ecology and Sociobiology 10:303-306.

GRINDAl, S. D. 1996. Habitat use by bats in fragmented forests. Pages 260-271 in R. M. R. Barclay and R. M Brigham, editors. Bats and Forests Symposium, Victoria, British Columbia, 19-21 October 1995. Working Paper 23/1996. Canadian Research Branch, British Columbia Ministry of Forests, Victoria, Canada.

- AND R. M. BRJGHAM. 1998. Short-term effect of small-scale habitat disturbance on activity by insectivorous bats. Joumal of Wildlife Management 62:996-1003.

Hanula, J. L., K. E. Franzreb, ano W. D. Peprer. 2000. Longleaf pine characteristics associated with arthropods available for red-cockaded woodpeckers. Journal of Wildlife Management 64:60-70.

Hart, J. A., G. L. Kurkland, JR., and S. C. Grossman. 1993. Relative abundance and habitat use by tree bats, Lasiurus spp., in southcentral Pennsylvania. Canadian
Field-Naturalist 107:208-212.

HAYEs, J. P., AND M. D. ADAM. 1996. The influence of logging riparian areas on habitat utilization by bats in western Oregon. Pages 228-237 in R. M. R. Barclay and R. M. Brigham, editors. Bats and Forests Symposium, Victoria, British Columbia, 19-21 October 1995. Working Paper 23/1996. Canadian Research Branch, British Columbia Ministry of Forests, Victoria, Canada.

Hickey, M. B. C., AND A. L. NEll Son. 1995. Relative activity and occurrence of bats in southwestern Ontario as determined by monitoring with bat detectors. Canadian Field-Naturalist 109:413-417.

HuL, J. E., AND J. D. SMmH. 1984. Bats: a natural history. University of Texas Press, Austin, USA.

Huff, M. H., J. F. Lehmkuhl., AND J. A. Young. 1993. Linking bat activity with landscape-level attributes using GIS. Northwest Science 67:131.

Humes, M. L., J. P. Hayes, And M. W. Collopy. 1999. Bat activity in thinned, unthinned, and old-growth forests in western Oregon. Journal of Wildlife Management $63: 553-561$.

HURLBERT, S. H. 1984. Pseudoreplication and the design of ecological field experiments. Ecological Monographs 54:187-211.

IMM, D. W., AND K. W. MCLEOD. 2005. Vegetation types. Pages 6-19 in J. C. Kilgo and J. I. Blake, editors. Ecology and management of a forested landscape: fifty years of natural resource stewardship on the Savannah River Site. Island Press, Washington, D.C., USA.

Johnson, J. B., M. A. Menzel, J. W. Edwards, AND W. M. Ford. 2002. A comparison of two acoustical bat survey techniques. Wildlife Society Bulletin 30:931-936.

Kalcounis, M. C., AND R. M. Brigham. 1995. Intraspecific variation in wing loading affects habitat use by little brown bats (Myotis lucifugus). Canadian Journal of Zoology 73:89-95.

, K. A. Hobson, R. M. Brigham, And K. R. Hecker. 1999. Bat activity in the boreal forest: importance of stand type and vertical strata. Joumal of Mammalogy 80:673-682.

Krusic, R. A., M. Yamasaki, C. D. Neffus, and P. J. Pekins. 1996. Bat habitat use in White Mountain National Forest. Journal of Wildlife Management 60:625-631.

LACKI, M. J., AND J. H. SCHWIERJOHANN. 2001. Day-roost characteristics of northern bats in mixed-mesophytic forest. Journal of Wildlife Management 65:482-488.

Mager, K. J., AND T. A. Neison. 2001. Roost-site selection by eastern red bats (Lasiurus borealis). American Midland Naturalist 145:120-126.

Menzel, J. M., M. A. Menzel, G. F. MCCracken, And B. R. Chapman. 2000b. Notes on bat activity above the forest canopy in the eastern United States. Georgia Journal of Science 58:212-216.

, M. A. Menzel, W. M. Ford, J. W. Edwards, S. Sheffeld, J. C. Kilgo, and M. Strayer Bunch. 2003 a. The distribution of the bats of South Carolina. Southeastern Naturalist 2:121-152.

MENZEL, M. A. 1998. The effects of group selection timber harvest in a southeastern bottomland hardwood community on the roosting and foraging behavior of tree-roosting bats. M.S. thesis, University of Georgia, Athens, USA.

2003b. An examination of factors influencing the spatial distribution of foraging bats in pine stands in the southeastern United States. Ph.D. dissertation, 
West Virginia University, Morgantown, USA.

T. C. Cakter, W. M. Ford, B. R. ChapMan, AND J. OzIER. 2000a. Summer roost tree selection by eastern red, Seminole, and evening bats in the Upper Coastal Plain of South Carolina. Proceedings of the Annual Conference of the Southeastern Association of Fish and Wildlife Agencies 54:304-313.

- J. M. Menzel, W. M. Ford, J. W. Enwards, T. C. Carter, J. B. Churchml, And J. C. Kngo. 2001 a. Notes on the homerange, habitat use, and diet of reproductively active male Rafinesque's big-eared bats, Comyonhinus rafmesqui, (Chiroptera: Vespertilionidae) in the Upper Coastal Plain of South Garolina. American Midland Naturalist 145:402-408.

, J. M. Menzel., T. C. Carter, W. M. Ford, AND J. W. EDWARDs. $2001 b$. Review of the forest habitat relationships of the Indiana bat (Myotis sodalis). U.S. Forest Service General Technical Report NE-284. U.S. Forest Service, Northeast Research Station, Newtown Square, Pennsylvania, USA.

, T. C. Cakter, W. M. Ford, AND B. R. Chapman. $2001 \mathrm{c}$. Characteristics of tree-roosts used by maternity colonies and solitary juvenile evening bats (Nycticeius humeralis) in a southern bottomland hardwood forest. American Midland Naturalist 145:112-119.

, T. C. Cirter, J. M. Menzel, W. M. Ford, and B. R. CHAPMAN. $2002 a$. Effects of group selection silviculture in bottomland hardwoods on the spatial activity patterns of bats. Forest Ecology and Management 162:209-218.

-, J. M. Menzel, J. C. Kilgo, W. M. Ford, T. C. CARTER, AND J. W. EDWARDS. 2003b. Bats of the Savannah River Site. U.S. Forest Service General Technical Report SRS-68. U.S. Forest Service, Southeast Research Station, Asheville, North Carolina, USA.

MontGomery, D. C. 1991. Design and analysis of experiments. Third edition. John Wiley and Sons, New York, USA.

NeuWeILER, G. 1984. Foraging, echolocation, and audition in bats. Naturwissenschaften 71:446-455.

O'Farrell, M. J., B. W. Miller, and W. L. Gannon. 1999. Qualitative identification of free-flying bats using the Anabat detector. Journal of Mammalogy 80:11-23.

Owen, S. F., M. A. Menzel, W. M. Ford, J. W. Edwards,
I. M. Menzel, B. R. CHAPMAN, P. B. WOOD, AND K. V. MULER 2004. Bat activity in harvested and intact forest stands in the Allegheny Mountains. Southern Joumal of Applied Forestry 21:154-159.

Parker, D. J., J. A. Cook, ANo S. W. LewIs. 1996. Effects of timber harvest on bat activity in southeastem Alaska's temperate rainforests. Pages 277-292 in R. M. R. Barclay and R. M. Brigham, editors. Bats and Forests Symposium, Victoria, British Columbia, 19-21 October 1995. Working Paper 23/1996. Canadian Research Branch, British Columbia Ministry of Forests, Victoria, Canada.

SAS InstmUte. 1990. SAS user's guide. Version 6.02. SAS Institute, Cary, North Carolina, USA.

Smmons, J. A., AND R. A. Stein. 1980. Acoustic imaging in bat sonar: echolocation signals and the evolution of echolocation. Journal of Comparative Physiology 135:61-84.

Trbbels, A. E., AND A. Kurta. 2003. Bat activity is low in thinned and unthinned stands of red pine. Canadian Journal of Forest Resources 33:2436-2442.

THomas, D. W. 1988. The distribution of bats in different ages of Douglas-fir forests. Journal of Wildlife Management 52:619-626.

U.S. Forest SERvick. 1988. The South's fourth forest. Resources Report 24. U.S. Forest Service, Washington, D.C., USA.

WEAR, D. N., AND J. G. GReis. 2002. Southern forest resource assessment. U.S. Forest Service General Technical Report SRS-54. U.S. Forest Service, Southern Research Station, Asheville, North Carolina, USA. WENGER, K. F. 1984. Forestry handbook. Second edition. John Wiley and Sons, New York, USA.

Williams, T. C., L. C. Ireland, AND J. M. Williams. 1973. High altitude flights of the free-tailed bat, Tadarida brasiliensis, observed with radar. Journal of Mammalogy 54:807-821.

WORKMAN, S. W., AND K. W. MCLEOD. 1990. Vegetation of the Savannah River Site: major community types. National Environmental Research Park Program Publication SRO-NERP-19. Savannah River Ecology Laboratory, Aiken, South Carolina, USA.

Associate Editor: Russell. 
